\title{
ALKALINE STRIPPING FOR ULTRA CLEAN BITUMEN FROM TAR SAND
}

\author{
R.T. Akande ${ }^{1 \#,}$ A.A. Adeleke1, P.O. Atanda ${ }^{1}$ \\ 1Obafemi Awolowo University, Department of Materials Science and Engineering, Ile-lfe, Nigeria
}

(Received: August 27, 2018; Accepted: June 7, 2019)

\begin{abstract}
This study reports the recovery of bitumen concentrate from Ondo tar sand by alkaline leaching stripping of the associated sand. Bitumen was extracted from the tar sand as received in un-stirred and stirred state in the oven and on the magnetic stirrer hotplate, respectively, at varying $3^{2}$ factorial design combinations of temperature and sodium hydroxide molar concentrations at 40 $\mathrm{g} / \mathrm{dm}^{3}$ pulp density. The tar sand was further subjected to bitumen dissolution test and recovery of bitumen at varying pulp density. The results obtained showed that bitumen was optimally stripped from the tar sand with initial bitumen content of about $34 \%$ in the stirred condition to produce a concentrate with grade and recovery percents of 98.82 and $99.41 \%$ of bitumen, respectively. The optimal leaching stripping was obtained at $2 \mathrm{M}$ sodium hydroxide concentration, at $90^{\circ} \mathrm{C}$ temperature and 25 minutes contact time. The ultra-clean bitumen obtained can serve as raw material input for petroleum products recovery and as a coking additive in blend formulation of coals for metallurgical coke making.
\end{abstract}

Key words: Tar sand; Bitumen; Leaching; Grade; Recovery; Cokemaking

\section{Introduction}

Tar sands also known as oil sands, are a combination of clay, sand, water, saturated with a dense and extremely viscous form of petroleum technically referred to as bitumen. They are impregnated sands that yield mixtures of liquid hydrocarbons, which require further processing other than mechanical blending before becoming finished petroleum products. Tar sand is found in various parts of the world including Canada, Madagascar, Venezuela, Russia, United States and Nigeria [1]. It is exceedingly rich in oil and other valuable minerals and metals in varying proportions. The tar sand deposits are composed primarily of quartz sand silt and clay, water and bitumen along with minor amount of metal minerals such as rutile, pyrite and zircon and gemstone like tourmaline [2].

Typically, oil sands contain about 75 percent inorganic matter, 10 to $18 \%$ bitumen, $10 \%$ silt and clay, and $5 \%$ water. The bitumen has high density, high viscosity, and high metal concentration. Oil sands are also low in hydrogen due to high carbon carbon-to-hydrogen molecule count. This thick, black, tar-like substance must be upgraded with an injection of hydrogen or by the removal of some of the carbon before it can be processed [3 - 5].

The bitumen content is what makes the oil sands a valuable energy resource. The bitumen content can vary within a deposit from 1 to $18 \%$. Once it is extracted from the sands, bitumen can be upgraded into crude oil and then refined into common petroleum products such as gasoline, kerosene or gas oil [4]. Nigeria has the fourth world largest deposit of natural bituminous tar sand estimated to be 31 billion metric tons in Ondo state alone with more reserves in Edo and Ogun States [6]. The bituminous materials, apart from the use in the production of crude oil, is useful in the petrochemical industry. The sulphur content of Nigeria tar sand constitutes a potential source of elemental sulphur for sulphuric and superphosphate fertilizer production plants. Other industrial applications include production of anticorrosive coatings, protection for electric cable, bonder adhesives and brake lining [7]. Bitumen extract from tar sand is also

\#Corresponding author: akanderukayat2@gmail.com

doi: 10.5937/JMMA1901017A 
used as an additive in the production of metallurgical grade coke $[8,9]$.

The presence of water layer around the sand grains enables the bitumen to be recovered more easily since the bonding forces between the bitumen and water are much weaker than those between the water and the sand grains $[10,11]$. Ondo tar sand was leached using sodium hydroxide and sodium carbonate for recovery of bitumen and also solubility test carried out on the tar sand using toluene [12]. Sodium hydroxide gave higher percentage of recovery than sodium carbonate for the same leach contact time. The bitumen recovery in the work was $98.05 \%$ with a bitumen grade of $97.70 \%$.

The present research is designed to obtain bitumen of grade and recovery exceeding 97.70 and $98.05 \%$, respectively; Ondo tar sand by factorial design based combinations of the leaching process variables in un-stirred and stirred conditions.

\section{Materials and methods}

\subsection{Materials}

\subsubsection{Sample collection}

The basic raw materials used in this work were lumps of bituminous tar sand obtained from Ondo State, Nigeria. About $50 \mathrm{~kg}$ lumps of the semi-solid black tar sand were collected from Agbabo-Loda village in Irele Local Government of the state. Irele Local Government is on the eastern boundary of Okitipupa Local Government which lies on longitude 40 $3^{\prime \prime}$ East of Greenwich Meridian and Latitude $50^{\circ} 45^{\prime \prime}$ and $80^{\circ} 15^{\prime \prime}$ North of the Equator. The choice of this location was based on the availability of plain bitumen in the zone coupled with its accessibility. The sample was collected from 2 open pits at a depth of about 3 feet. After the field sampling, the lumps of tar sand obtained were kept in large plastic bags.

\subsubsection{Sample preparation}

The tar sand black lumps were crushed and properly ground with a steel rod. The ground tar sand was then homogenized in a mortar by pounding with a pestle. The resulting tar sand mass gave a finer particle and bitumen mixture.

\subsubsection{Methods}

\subsubsection{Solubility test}

One gram of the homogenized tar sand was placed in $0.25 \mathrm{dm}^{3}$ beaker and $25 \mathrm{~cm}^{3}$ of $99.5 \%$ toluene was added to make a slurry at about 40 $\mathrm{g} / \mathrm{dm}^{3}$ pulp density. The mixture was stirred with a glass rod for 2 minutes and left to react for 1 minute. The test was carried out in duplicates. The test was repeated for 2, 3, 4, 5, 6 and 7 minutes of reaction. A blank test was as well carried out using water instead of toluene for these durations.

\subsubsection{Atmospheric oven leaching}

The tar sand was leached in laboratory oven model number LKM DHG-9101-1SA using $3^{2}$ factorial design, with temperature and concentration as process variables. The tar sand was leached at three different temperatures $-T_{1}, T_{2}$ and $T_{3}$ where $T_{1}$ $=50{ }^{\circ} \mathrm{C}, \mathrm{T}_{2}=70^{\circ} \mathrm{C}$ and $\mathrm{T}_{3}=90^{\circ} \mathrm{C}$ and three different concentrations of sodium hydroxide $C_{1}, C_{2}$, $\mathrm{C}_{3}$ where $\mathrm{C}_{1}=0.5 \mathrm{M}, \mathrm{C}_{2}=1 \mathrm{M}$ and $\mathrm{C}_{3}=2 \mathrm{M}$. The nine combinations of the leaching $T_{1} C_{1}, T_{1} C_{2}, T_{1} C_{3}$, $\mathrm{T}_{2} \mathrm{C}_{1}, \mathrm{~T}_{2} \mathrm{C}_{2}, \mathrm{~T}_{2} \mathrm{C}_{3}, \mathrm{~T}_{3} \mathrm{C}_{1}, \mathrm{~T}_{3} \mathrm{C}_{2}$ and $\mathrm{T}_{3} \mathrm{C}_{3}$ are shown in Table 1. One gram of tar sand as received was placed in $25 \mathrm{ml} 0.5 \mathrm{M}$ sodium hydroxide in a 0.25 $\mathrm{dm}^{3}$ erlenmeyer flask reactor. The slurry was then homogenized by stirring for 5 minutes and covered with Al foil.

One gram of tar sand as received was placed in $25 \mathrm{~cm}^{3} 0.5 \mathrm{M}$ sodium hydroxide in a $0.25 \mathrm{dm}^{3}$ erlenmeyer flask reactor. The slurry was then homogenized by stirring for 5 minutes, covered with Al foil and transferred into the oven for leaching. The oven was set at $50^{\circ} \mathrm{C}$ to give the test combination $\mathrm{T}_{1} \mathrm{C}_{1}$ and left for 30 minutes after attaining the set temperature. The bitumen concentrate was skimmed off, dried and weighed. The bitumen concentrate was also tested for grade and recovery as described below. The procedure was repeated for test combinations $T_{1} C_{2}, T_{1} C_{3}, T_{2} C_{1}, T_{2} C_{2}, T_{2} C_{3}$, 
$\mathrm{T}_{3} \mathrm{C}_{1}, \mathrm{~T}_{3} \mathrm{C}_{2}$ and $\mathrm{T}_{3} \mathrm{C}_{3}$. A blank test was as well carried out using $25 \mathrm{~cm}^{3}$ of distilled water at about $40 \mathrm{~g} / \mathrm{dm}^{3}$ pulp density in a $0.25 \mathrm{dm}^{3}$ erlenmeyer flask reactor. The slurry was stirred for 5 minutes to homogenize it and then transferred into the oven for leaching at $90{ }^{\circ} \mathrm{C}$ for 30 minutes.

Table 1. Factorial combinations of leaching variables

\begin{tabular}{|c|c|c|}
\hline Temperature & Concentration & Combination \\
\hline$T_{1}$ & $\mathrm{C}_{1}$ & $\mathrm{~T}_{1} \mathrm{C}_{1}$ \\
\hline $\mathrm{T}_{1}$ & $\mathrm{C}_{2}$ & $\mathrm{~T}_{1} \mathrm{C}_{2}$ \\
\hline $\mathrm{T}_{1}$ & $\mathrm{C}_{3}$ & $\mathrm{~T}_{1} \mathrm{C}_{3}$ \\
\hline $\mathrm{T}_{2}$ & $\mathrm{C}_{1}$ & $\mathrm{~T}_{2} \mathrm{C}_{1}$ \\
\hline $\mathrm{T}_{2}$ & $\mathrm{C}_{2}$ & $\mathrm{~T}_{2} \mathrm{C}_{2}$ \\
\hline $\mathrm{T}_{2}$ & $\mathrm{C}_{3}$ & $\mathrm{~T}_{2} \mathrm{C}_{3}$ \\
\hline $\mathrm{T}_{3}$ & $\mathrm{C}_{1}$ & $\mathrm{~T}_{3} \mathrm{C}_{1}$ \\
\hline $\mathrm{T}_{3}$ & $\mathrm{C}_{2}$ & $\mathrm{~T}_{3} \mathrm{C}_{2}$ \\
\hline $\mathrm{T}_{3}$ & $\mathrm{C}_{3}$ & $\mathrm{~T}_{3} \mathrm{C}_{3}$ \\
\hline
\end{tabular}

\subsubsection{Determination of optimal leaching time}

The sample slurry at about $40 \mathrm{~g} / \mathrm{dm}^{3}$ in erlenmeyer flask reactor covered with Al foil was leached on Stuart magnetic stirrer model no R000101019 for 5 minutes contact time in $1 \mathrm{M}$ sodium hydroxide solution at $90 \mathrm{rev} / \mathrm{min}$. After 5 minutes, the erlenmeyer flask reactor was removed from the magnetic stirrer hotplate and the bitumen was skimmed off. The test was repeated at 1.5, 2, $2.5,3,3.5$ and $4 \mathrm{M}$ concentrations and varied contact times of $10,15,20,25$ and 30 minutes. The procedure was repeated for 10,15, 20, 25 and 30 minutes contact time.

A blank test was also carried out using at the same $40 \mathrm{~g} / \mathrm{dm}^{3}$ pulp density in a $0.25 \mathrm{dm}^{3}$ erlenmeyer flask reactor. The slurry was stirred for 5 minutes to homogenize it and the erlenmeyer was covered with an aluminium foil and then placed on the magnetic stirrer hotplate which agitates the slurry.

\subsubsection{Leaching on magnetic stirrer hot plate}

The tar sand was leached on a magnetic stirrer hotplate using $3^{2}$ factorial design, that is, at three levels of temperature and concentration process variables as in section 3.2.3. The $0.25 \mathrm{dm}^{3}$ beaker reactor with tar sand slurry having $25 \mathrm{~cm}^{3} 0.5 \mathrm{M}$ sodium hydroxide at about $40 \mathrm{~g} / \mathrm{dm}^{3}$ pulp density was initially homogenized for 5 minutes. The beaker was placed on Stuart magnetic stirrer hotplate model number R000101019, the magnetic stirrer was set to $50^{\circ} \mathrm{C}$ and $90 \mathrm{rev} / \mathrm{min}$ to give the $\mathrm{T}_{1} \mathrm{C}_{1}$ test combination. The magnetic stirrer was switched on and the tar sand pulp was allowed to react with the sodium hydroxide leachate for 30 minutes. At the end of the 30 minutes, the bitumen concentrate was skimmed off and the leachate was filtered to remove the remaining bitumen. The procedure was repeated for combinations $T_{1} C_{2}, T_{1} C_{3}, T_{2} C_{1}, T_{2} C_{2}$, $\mathrm{T}_{2} \mathrm{C}_{3}, \mathrm{~T}_{3} \mathrm{C}_{1}, \mathrm{~T}_{3} \mathrm{C}_{2}$ and $\mathrm{T}_{3} \mathrm{C}_{3}$.

\subsubsection{Determination of bitumen recovery and grade}

The mass of bitumen in the concentrate was determined by dissolving the bitumen obtained from each of the $T_{1} C_{1}$ combination with $25 \mathrm{~cm}^{3}$ of toluene for 10 minutes contact time at the same pulp density of $40 \mathrm{~g} / \mathrm{dm}^{3}$. The leaching of the concentrate with toluene was carried out for 10 minutes until the bitumen was fully dissolved from the associated sand. The remaining sand was dried, weighed and the value was subtracted from the initial mass of the tar sand to determine the mass of the bitumen in the concentrate. The leachate was filtered to remove excess sand. The test was repeated for the $T_{1} C_{2}$, $\mathrm{T}_{1} \mathrm{C}_{3}, \mathrm{~T}_{2} \mathrm{C}_{1}, \mathrm{~T}_{2} \mathrm{C}_{2}, \mathrm{~T}_{2} \mathrm{C}_{3}, \mathrm{~T}_{3} \mathrm{C}_{1}, \mathrm{~T}_{3} \mathrm{C}_{2}$ and $\mathrm{T}_{3} \mathrm{C}_{3}$ combinations.

The recovery and grade was calculated as follows:

$$
\begin{aligned}
& \% \text { Recovery }=\frac{\text { mass of bitumen in the concentrate }}{\text { mass of bitumen in tar sand sample }} 100 \\
& \% \text { Grade }=\frac{\text { mass of bitumen in the sample/concentrate }}{\text { mass of sample/concentrate }} 100 \text { (2) }
\end{aligned}
$$

\subsubsection{Leaching stripping of sand on electric hotplate}

A tar sand slurry of about $40 \mathrm{~g} / \mathrm{dm}^{3}$ pulp density prepared by mixing $25 \mathrm{~cm}^{3} 1.5 \mathrm{M}$ of sodium 
hydroxide and $1 \mathrm{~g}$ of tar sand in a $0.50 \mathrm{dm}^{3}$ beaker. The beaker with the tar sand slurry was then placed on the HP-11 electric hot plate. The slurry was stirred continuously with a glass rod to agitate it for the recovery of bitumen from the tar sand. This was done for 30 minutes and after that the bitumen was decanted off and the residue was washed with water to remove bitumen. The residue was further washed with toluene to dissolve traces of bitumen in the tailings. The residue was then dried at $70^{\circ} \mathrm{C}$ in the oven. The procedure was then repeated for $2,3,4$, $5,6,7,8,9$ and $10 \mathrm{~g}$ translating to about 80,120 , $160,200,240,280,320$ and $400 \mathrm{~g} / \mathrm{dm}^{3}$ pulp density, respectively. The same procedure was further repeated using $30 \mathrm{~g}$ of tar sand and the slurry was prepared by mixing $0.30 \mathrm{dm}^{3} 1.5 \mathrm{M}$ of sodium hydroxide and $30 \mathrm{~g}$ of tar sand in a $0.50 \mathrm{dm}^{3}$ beaker. The procedure was repeated severally until $7 \mathrm{~kg}$ of tar-free sand was recovered. A blank test was carried out using $25 \mathrm{ml}$ of distilled water and $1 \mathrm{~g}$ tar sand in a $0.50 \mathrm{dm}^{3}$ beaker reactor. The beaker with the tar sand slurry was then placed on the HP-11 electric hot plate. The slurry was stirred continuously with a glass rod to agitate it for the recovery of bitumen from the tar sand.

\section{Results and discussion}

After leaching the tar sand as-received with toluene for 3 minutes, the bitumen recovery was $34 \%$. Table 2 shows that the peak time for leaching bitumen in toluene is 3 minutes. It was also observed that water could not strip bitumen from the tar sand despite its longer contact time with the sample as the tar sand remains the same mass. Figure 1 shows the mass of the sand residue determined as a function of time. It was observed that the bitumen in the tar sand gets completely dissolved in toluene after 3 minutes as there was no further increase in residual sand mass after 3 minutes. The percent bitumen grade and recovery obtained were 98.82 and $99.41 \%$ which is higher than 97.70 and $98.05 \%$ obtained by Adeleke et al. [12]. Hence, there is an improvement in the recovery of the bitumen and its grade to ultra clean state. The initial content of about $34 \%$ bitumen or extra heavy crude oil in the Ondo oil sand is much higher than the typical $10 \%$ in oil sands in other countries [2]. The improvement obtained may be due to the increased pulp stirring applied during the bitumen stripping stage, higher concentration of the leachate or a combination of these factors [13]

Table 2. Peak time for leaching of bitumen in toluene

\begin{tabular}{|c|c|}
\hline $\begin{array}{c}\text { Contact time } \\
\text { (minutes) }\end{array}$ & $\begin{array}{c}\text { Sand Residue } \\
\text { (g) }\end{array}$ \\
\hline 1 & 0.74 \\
\hline 2 & 0.72 \\
\hline 3 & 0.66 \\
\hline 4 & 0.66 \\
\hline 5 & 0.66 \\
\hline 6 & 0.66 \\
\hline 7 & 0.66 \\
\hline
\end{tabular}

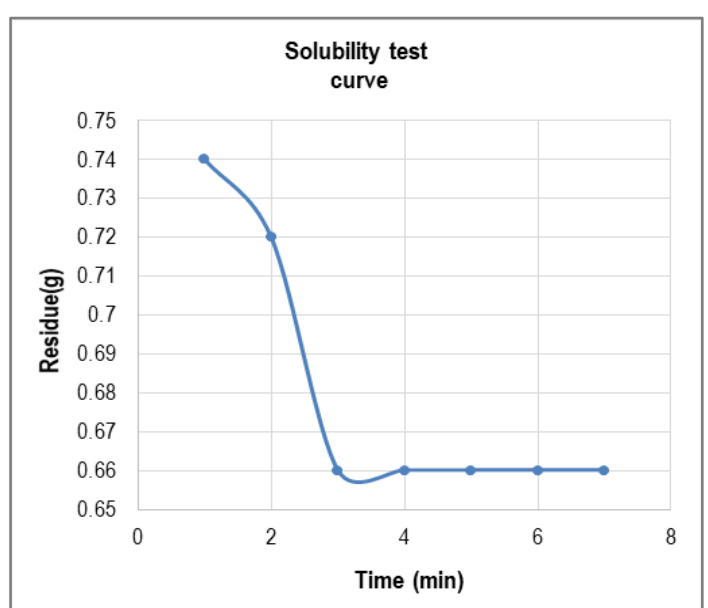

Figure 1. Residual sand recovered with increasing contact time when tar sand was dissolved in toluene

\subsection{Determination of the optimal concentration and temperature}

Table 3 lists the grades and recoveries obtained at different combination of temperature and concentration of sodium hydroxide for leaching of bitumen on magnetic stirrer hotplate. It was observed that the combination $\mathrm{T}_{3} \mathrm{C}_{3}\left(\mathrm{~T}_{3}=90^{\circ} \mathrm{C}\right.$ and $\mathrm{C}_{3}=2 \mathrm{M}$ ) gave the best grade and recovery percents of 98.82 and $99.41 \%$, respectively. The results strongly indicate that temperature and concentration of the leachate determines the 
effectiveness of the leaching which in turn determines the grade and the recovery of the bitumen obtained. The product obtained is ultra clean. The blank test showed that water cannot successfully strip bitumen from tar sand using a magnetic stirrer as the tar sand remained unchanged. A bitumen concentrate with grade and recovery percents of 98.82 and $99.41 \%$, respectively were obtained which are higher than $98.05 \%$ recovery and $97.70 \%$ grade obtained in earlier work [12]. Hence, bitumen from Ondo tar sand has been recovered with higher grade and recovery.

Table 3. Grades and recoveries of bitumen recovered for the $3^{2}$ factorial design experiment on the magnetic stirrer hotplate

\begin{tabular}{|c|c|c|}
\hline Combination & Grade (\%) & Recovery (\%) \\
\hline $\mathrm{T}_{1} \mathrm{C}_{1}$ & 55.00 & 97.06 \\
\hline $\mathrm{T}_{1} \mathrm{C}_{2}$ & 65.40 & 97.65 \\
\hline $\mathrm{T}_{1} \mathrm{C}_{3}$ & 79.10 & 98.24 \\
\hline $\mathrm{T}_{2} \mathrm{C}_{1}$ & 62.96 & 98.82 \\
\hline $\mathrm{T}_{2} \mathrm{C}_{2}$ & 68.00 & 99.41 \\
\hline $\mathrm{T}_{2} \mathrm{C}_{3}$ & 97.14 & 99.41 \\
\hline $\mathrm{T}_{3} \mathrm{C}_{1}$ & 84.60 & 98.82 \\
\hline $\mathrm{T}_{3} \mathrm{C}_{2}$ & 91.89 & 99.41 \\
\hline $\mathrm{T}_{3} \mathrm{C}_{3}$ & 98.82 & 99.41 \\
\hline
\end{tabular}

The grade and recovery rate at different combination of temperature and concentration are also shown in Figure 2. The graph indicates that the leaching rate is greatly influenced by concentration and temperature as good grades and recoveries were observed as the temperature and the concentration increase. The maximum positive leaching effect was observed at the highest temperature of $90{ }^{\circ} \mathrm{C}$ and highest molar concentration of $2 \mathrm{M}$. The $\left(\mathrm{T}_{3} \mathrm{C}_{3}\right)$ combination thus had the best recovery and grade values. It has been established in literature that leaching rate generally increases with increasing temperature and concentration of the leachate [13] An equation was developed which showed that the leaching rate of gibbsite increases almost squarely with concentration and exponentially with temperature [13].

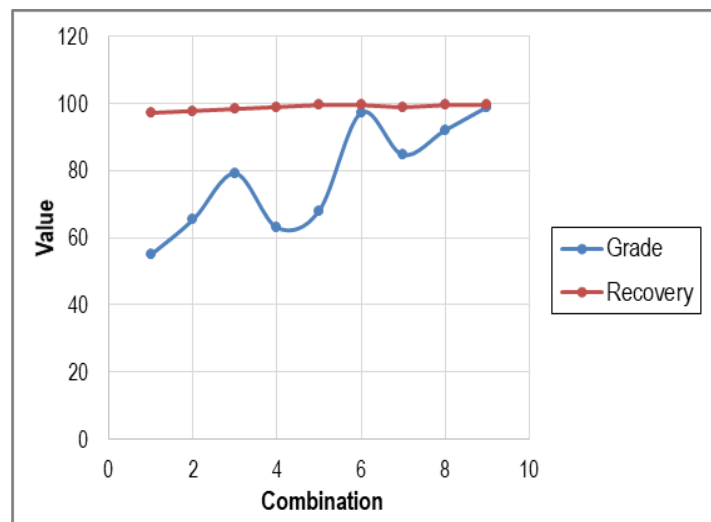

Figure 2. Grades and recoveries of bitumen at factorial combinations of temperature and concentration

\subsection{Determination of the effect of slurry stirring}

Figure 3 shows that there was only minor bitumen separation after 30 minutes of leaching tar sand in the oven, the highest recovery being about $41 \%$ of the initial mass of the sample treated. The use of increasing sodium hydroxide leachate concentrations of $\mathrm{C}_{1}=0.5 \mathrm{M}, \mathrm{C}_{2}=1.0 \mathrm{M}$, and $\mathrm{C}_{3}=$ $2.0 \mathrm{M}$ increasing temperatures of $\mathrm{T}_{1}=50^{\circ} \mathrm{C}, \mathrm{T}_{2}=$ $70{ }^{\circ} \mathrm{C}$ and $\mathrm{T}_{3}=90^{\circ} \mathrm{C}$ produced only minor yield in bitumen. In contrast, the yield of bitumen on the magnetic stirrer hotplate within the same contact time was significantly higher at $99.41 \%$ of the initial mass of the sample (Table 3). Hence, the result shows that the stirring action was more important than both temperature and concentration variables whose increases produced low bitumen yield after 30 minutes of the oven leaching. Furthermore, the oven leaching result shows that water is not a potent leachate as it had no effect on the striping of bitumen from the tar sand for all the leaching contact times. Stirring agitation of slurry has been reported to produce increase leaching rate [13]. The results obtained strongly suggests that the semi-pilot and pilot scale upgrading of the present research should be carried out with a magnetic stirrer or autoclave system under intense stirring because of the increased pulp density at say 7 and $250 \mathrm{~kg}$ mass, respectively. 


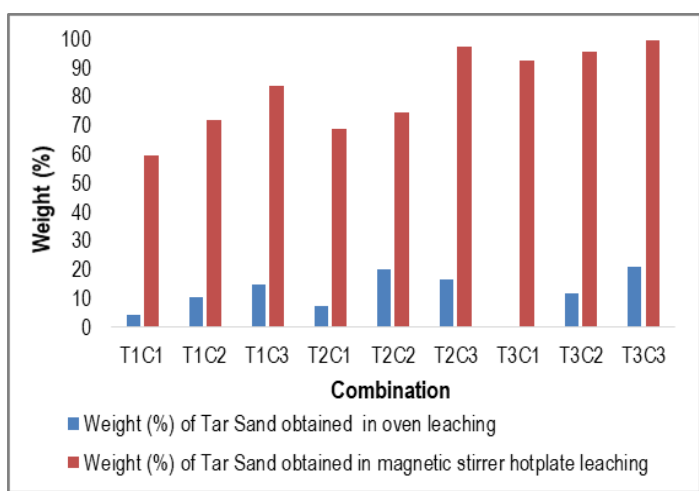

Figure 3. Leaching recovery of bitumen from tar sand in oven and magnetic stirrer after 30 minutes

\subsection{Determination of optimal leaching time}

Figure 4 shows the mass of the residue after the bitumen was leached away as a function of concentration and contact time process variables. It was also observed from the blank test, that water is not a potent leachate for stripping bitumen from the tar sand as the mass of the tar sand remained unchanged after 30 minutes contact with water leachate.

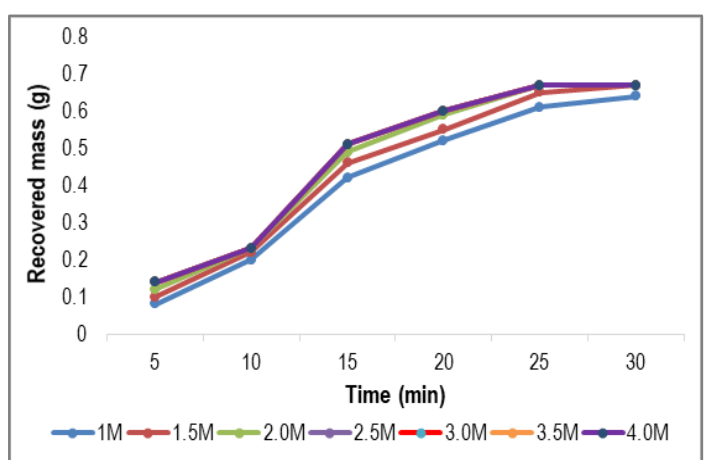

Figure 4. Recovered mass of tar free sand at different concentrations and contact time in magnetic stirrer hot plate leaching

It was observed from Figure 5 that the bitumen leaching from the tar sand was also time dependent as the tar sand must have sufficient contact time with the leachate for the leaching reaction to take place. Figure 5 also indicates that the time required for the leaching to occur was also dependent on the concentration of the leachate. At higher concentration, lesser time was required unlike at lower concentration. The peak bitumen recovery of $99.41 \%$ was obtained at 25 minutes contact time for $2.0 \mathrm{M}$ leachate concentration. The increase of the contact time beyond 25 minutes did not yield higher bitumen recovery. It was also observed that a decrease in the molar concentration required an increase in the contact time for the bitumen recovery.

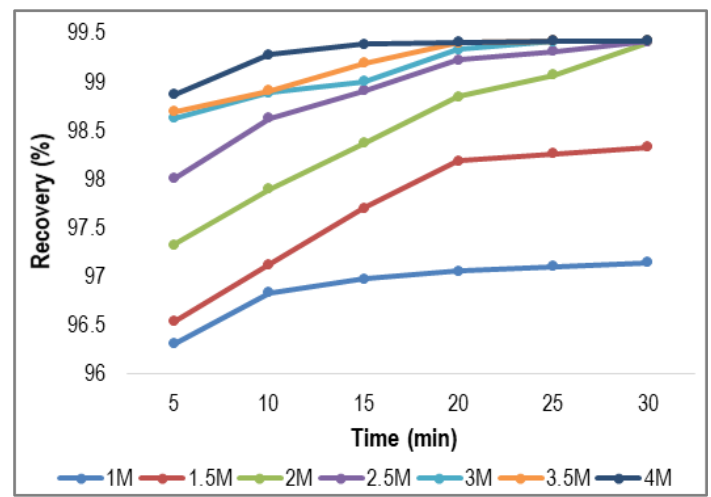

Figure 5. Recovery (\%) of bitumen at different concentrations and contact time on magnetic stirrer hot plate leaching

The composite graph, Figure 5, shows that the mass of bitumen leached increases with increasing contact time and increasing leachate concentrations. It could be seen from the curves that bitumen recovery was low at 5 minutes and increased with contact until the maximum was attained at 25 minutes at each concentration. It was observed that the percentage recovery and grade increases with increasing contact time and increasing leachate concentration. Figure 4 shows that the mass recovered at 10 minutes contact time was almost the same for 1.5 to $4 \mathrm{M}$ concentrations. It was further observed that the mass recovered also became almost equal after 30 minutes contact time for concentrations 1.5 to $4 \mathrm{M}$ and is only marginally higher, that is, $0.019 \mathrm{~g}$, than that at $1 \mathrm{M}$ concentration. The results obtained suggest that leaching at 1 and $2 \mathrm{M}$ lower concentrations may be sufficient in economic term. Figure 5 shows that the bitumen recovery percentage generally increases with increasing contact time and concentration. 
However, it was observed that the recovery percentage becomes almost equal for molar concentrations 2 to $4 \mathrm{M}$ at 30 minutes contact time. This further strongly suggests that a lower concentration of $2 \mathrm{M}$ may be sufficient to obtain the highest bitumen recovery after the 30 minutes contact time. The contact time of 30 minutes is further shown to be an optimal leaching duration. Leaching tests carried out at concentration between 0.1 and $3 \mathrm{M}$, with a small variation between each concentration, showed that there is an increase in rate of leaching with increase in concentration, however, further increasing of the concentration leads to decrease in rate of leaching. Figure 6 shows that grade $\%$ generally increase with contact and molar concentration and became equal for the 1.5 to $4 \mathrm{M}$ concentrations at 10 minutes and then for 2 to $4 \mathrm{M}$ at 30 minutes contact time. The results again strongly suggest that leaching at $2 \mathrm{M}$ concentration at a contact time of 30 minutes may be sufficient and hence most economical.

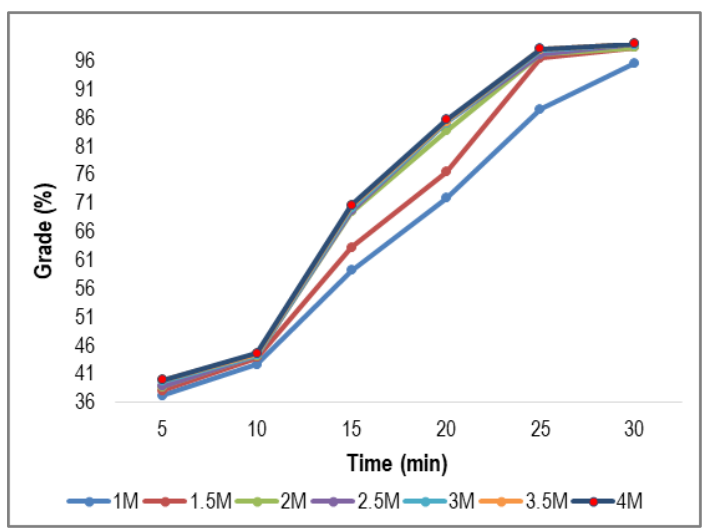

Figure 6. Grade (\%) of recovered bitumen at varying concentration of sodium hydroxide and contact time on magnetic stirrer hot plate leaching

\subsection{Leaching stripping of sand on electric hotplate}

The weight percent of recovered tar-free sand reduces with increase in the mass of the tar sand, as shown in Figure 7, which indicates that the percentage recovery decreases as the pulp density increases. Hence, pulp density is one of the factors that affect leaching and hence the bench scale leaching was carried out at about $40 \mathrm{~g} / \mathrm{dm}^{3}$. It was observed that the least bitumen recovery of $55 \%$ on the magnetic stirrer hotplate was higher than the highest recovery of $45 \%$ on the ordinary hotplate. This confirms that slurry stirring is an important process variable in leaching hydrometallurgy [13].

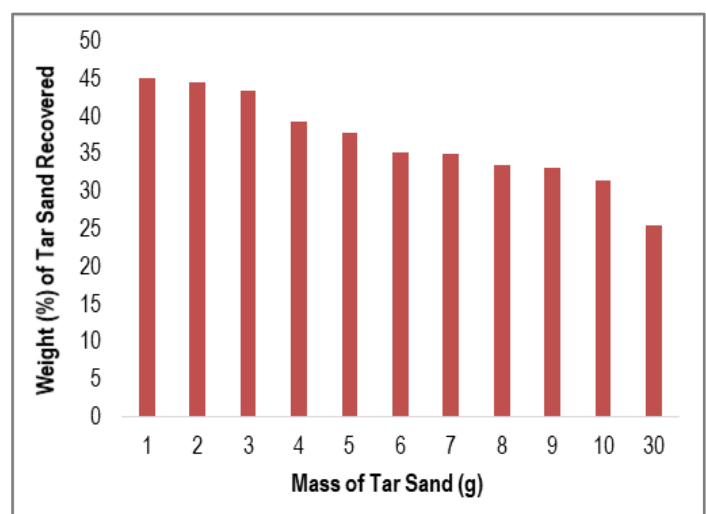

Figure 7. Weight (\%) of tar sand recovered on stripping on electric hot plate

\subsection{Mechanism of leaching bitumen}

Each grain of tar sand is surrounded by a film of water that is in turn covered by the heavy bitumen oil. The presence of water layer around the grains enables the bitumen to be recovered more easily since the bonding forces between the bitumen and water are much weaker than those between the water and the sand grains [10]. The alkaline leaching caused neutralization of organic acids with the formation of natural surfactants in the form of corresponding soluble salts, rise in the $\mathrm{pH}$ of a medium, species ionization and change in electric charges at the system interfaces. The positive influence of these factors favor a decrease in adhesion forces between bitumen and quartz, an increase in electrostatic repulsive forces, separation of bitumen from sand particles and its rise to the aqueous solution surface. Figure 8 shows the microstructure of tar sand and the mechanism of bitumen stripping from sand [10]. The flow diagram for the alkaline leaching recovery of the bitumen is shown in Figure 9. 


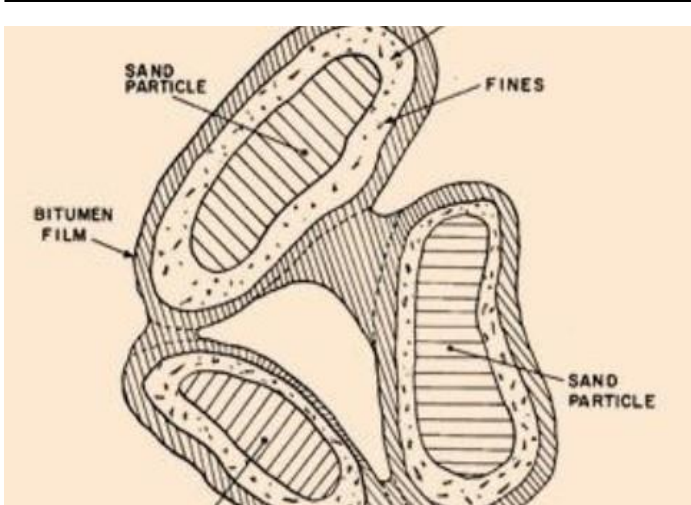

Figure 8. Microstructure of tar sand (Source: Adapted from Takamura [10])

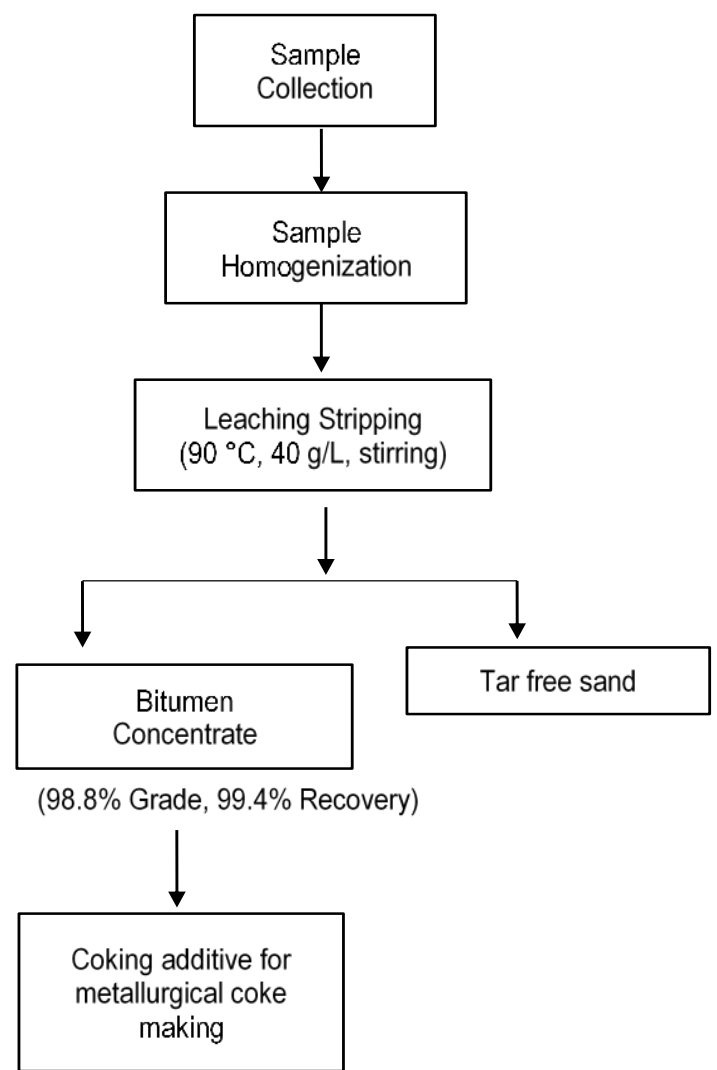

Figure 9. Flow diagram for alkaline leaching extraction of bitumen and the application of the bitumen extract

\section{Conclusions}

The sand impregnated Ondo tar sand was successfully and optimally stripped of its bitumen content in a stirred condition to produce an ultra- clean bitumen with grade and recovery percent of 98.82 and $99.41 \%$ respectively at combination $\mathrm{T}_{3} \mathrm{C}_{3}$, where $\mathrm{T}_{3}=90^{\circ} \mathrm{C}$ and $\mathrm{C}_{3}=2 \mathrm{M}$ of sodium hydroxide at 30 minutes contact time. The ultra-clean obtained bitumen can serve as raw material input for petroleum products recovery and as a coking additive in blend formulation of coals for metallurgical coke making.

\section{References}

[1] Falebita, O.A., Koul, S. (2015) Sustainable development of oil sands and host communities: preliminary system dynamics assessment. In: MakeLearn and TIIM Joint International Conference. Bari, Italy, Proceedings, 2095-2109.

[2] Erdogan, L. (2011) Dielectric properties of oil sands at $2.45 \mathrm{GHz}$ determined with rectangular cavity resonator. M.Sc. Thesis, University of Montreal, Montreal, QC, Canada.

[3] Humphries, M. (2008) North American oil sands: history of development, prospects for the future, link of web pages:

https://apps.dtic.mil/dtic/tr/fulltext/u2/a477532.p df, (accessed date: 20.06.2019.).

[4] Strausz, O.P., Lown, E.M. (2003) The chemistry of Alberta oil sands, bitumens and heavy oils. Alberta Energy Research Institute, Calgary, Alberta, Canada, 588-592.

[5] Schlosberg, R.H., Jordan, R.D., Diefenthal, E.L. (2016) U.S. Patent No. 9,410,089. Washington, D.C: U.S. Patent and Trademark Office.

[6] Emmanuel, E., Ajibade, O.M. (2014) Elemental Composition and Geochemistry of Heavy Oil in Parts of Eastern Dahomey Basin, Southwestern Nigeria. Journal of Environment and Earth Science, 4 (12), 18-25.

[7] Adegoke, O.S., Ako, B.D., Enu, E.I. (1980) Geotechnical Investigations of the Ondo State Bituminous Sands, Geology and Reserves Estimate. Unpublished manuscript. Department of Geology, University of lle-lfe, Nigeria.

[8] Weskamp, W., Rohde, W., Stewen, W., Habermehl, D. (1987) Greater coke strength through reactive additives to coking blends. In: 
II International Cokemaking Congress. Essen, Germany, Proceedings, 13-18.

[9] Ryemshak, S.A., Jauro, A., Chindo, I.Y., Ekanem, E.O., Ayeni, F.A. (2015) By-Product from Pyrolysis of Tar-Sand in Blend with GrayKing Assessed Nigerian Coals for Coke Production. International Journal of Chemistry and Materials Research, 3 (11), 154-164.

[10] Takamura, K., Chow, R.S. (1982) A Mechanism for Initiation of Bitumen Displacement from Oil Sand. In: Annual Technical Meeting, Petroleum
Soc. of CIM. Calgary, Canada, 82-83-88.

[11] SrinivasaRajagopalan, S. (2010) Study of bitumen liberation from oil sands ores. Masters Abstracts International, 49 (2).

[12] Adeleke, A.A., Ibitoye, S.A., Oladokun, C.B., Oluwasegun, K.M. (2011). An Evaluation of the Hot Aqueous Caustic Leaching of Nigerian Ondo Tar Sand. Petroleum and Coal, 53 (4), 320-323.

[13] Ghosh, A., Ray, H.S. (1991) Principles of extractive metallurgy. New Age International.

\title{
ALKALNA EKSTRAKCIJA ULTRA ČISTOG BITUMENA IZ NAFTNOG PESKA
}

\author{
R.T. Akande ${ }^{1 \#, ~ A . A . ~ A d e l e k e ' 1, ~ P . O . ~ A t a n d a ~}{ }^{1}$
}

${ }^{1}$ Obafemi Awolowo University, Department of Materials Science and Engineering, lle-Ife, Nigeria

(Primljen: 27. Avgust 2018.; Prihvaćen: 7. Jun 2019.)

\begin{abstract}
Izvod
U ovom radu je prikazano izdvajanje koncentrata bitumena iz naftnog peska iz države Ondo u Nigeriji postupkom alkalnog luženja. Bitumen je izdvojen iz naftnog peska koji je zagrevan u pećnici i mešan u magnetnoj mešalici sa grejnom pločom na različitim temperaturama dobijenim $3^{2}$ faktorskim dizajnom pri različitim molarnim koncentracijama natrijum hidroksida i gustine pulpe od $40 \mathrm{~g} / \mathrm{dm}^{3}$. Naftni pesak je zatim podvrgnut ispitivanju rastvaranja bitumena, kao i njegovog izdvajanja pri različitim gustinama pulpe. Dobijeni rezultati su pokazali da je optimalno izdvajanje bitumena postignuto iz naftnog peska sa početnim sadržajem bitumena od 34\% u mešanom stanju pri čemu se dobija koncentrat kvaliteta 98,82\% i iskorišćenje od 99,41\% bitumena. Optimalna ekstrakcija luženjem je postignuta kada je koncentracija natrijum hidroksida bila $2 \mathrm{M}$, temperatura $90{ }^{\circ} \mathrm{C}$, a vreme kontakta 25 minuta. Dobijeni ultra čisti bitumen može da se koristi kao sirovina za dobijanje naftnih derivata, a takođe i kao aditiv za mešavinu uglja koja se koristi prilikom metalurške proizvodnje koksa.
\end{abstract}

Ključne reči: Naftni pesak; Bitumen; Luženje, Kvalitet; Iskorišćenje; Proizvodnja koksa. 